\title{
Analisis Implementasi Islamic Store Attributes dan Bauran Pemasaran dalam Perspektif Islam (Survey pada La-Tansa Gontor Departement Store Ponorogo)
}

\author{
Dhika Amalia Kurniawan', Faisal Setiawan Fajri \\ Fakultas Ekonomi dan Manajemen, Universitas Darussalam Gontor Ponorogo \\ dhika.amalia@unida.gontor.ac.id ${ }^{1}$
}

\begin{abstract}
This arrangement aims to find out the Implementation of Islamic store attributes and marketing mix from Islamic perspective at La-Tansa Gontor Department Store. Implementation of Islamic store attributes and marketing mix from the Islamic perspective in the store is highly recommended that Muslim business people still maintain the norms of religion in business and establish a business strategy in accordance with Islamic Shari'a. With a qualitative approach, data collection with observation, interview and documentation techniques. The data analysis used is descriptive analysis technique with the aim to describe the data that researcher collect about Implementation of Islamic store attributes and marketing mix from Islamic perspective in La-Tansa Gontor Department Store.
\end{abstract}

Keywords: Islamic Store Attributes, Marketing mix, Islamic perspective, La-Tansa Gontor

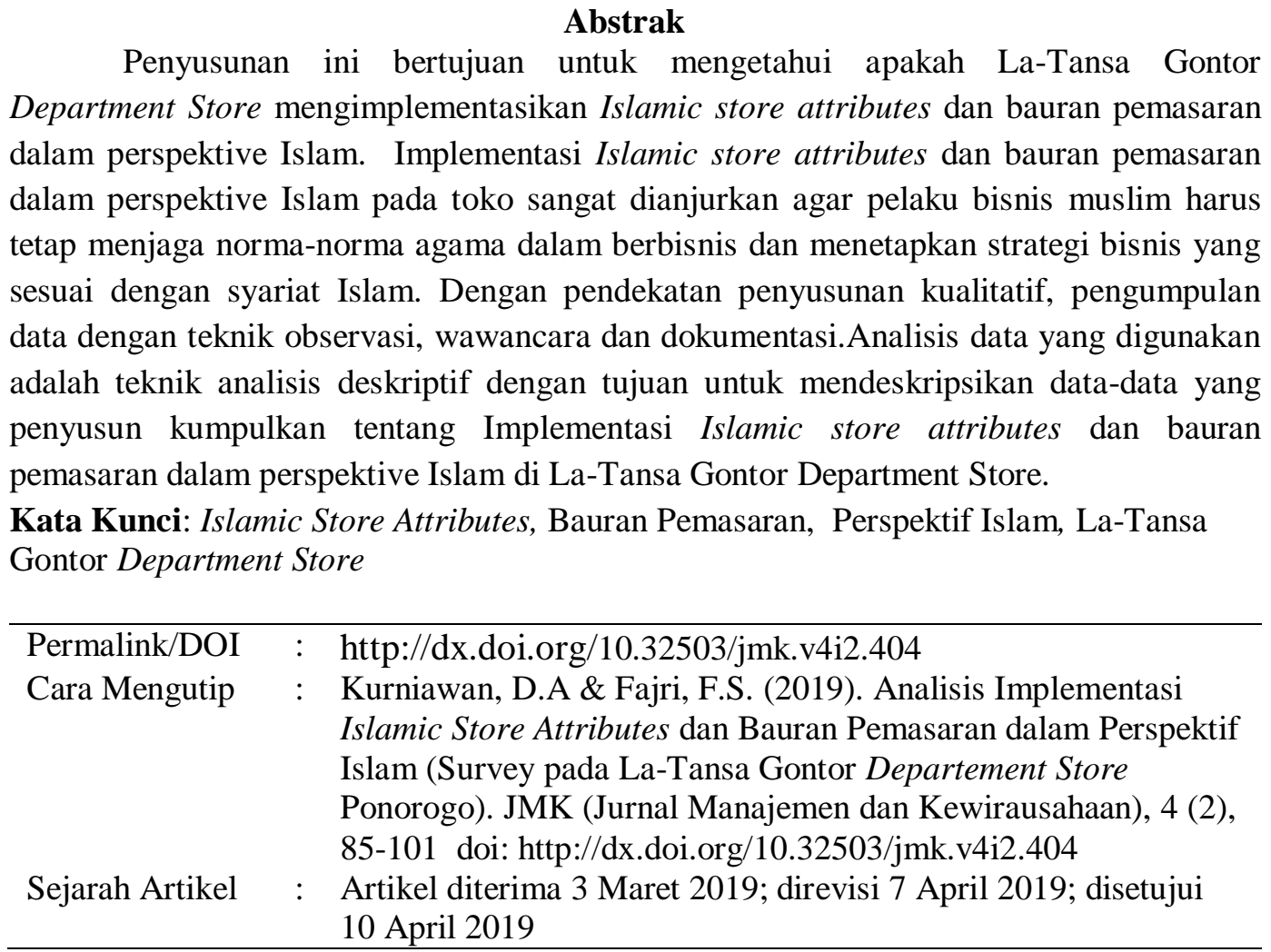

Alamat korespondensi :

Jl. Raya Demangan Siman

Universitas Darussalam Gontor

Ponorogo, Jawa Timur 


\section{Pendahuluan}

Bisnis saat ini merupakan bentuk dari aktivitas ekonomi yang dapat membangun serta memajukan perekonomian bangsa dan negara. Kehidupan masyarakat tidak lepas bergantung kepada aktivitas ekonomi. Mulai dari membangun bisnis ritel, berbisnis dalam bidang jasa, membangun bisnis manufaktur dan lain sebagainya. Hal ini akan menimbulkan persaingan diantara pelaku bisnis agar tetap bertahan dan berkembang. Berbagai cara dilakukan oleh pelaku bisnis mulai bentuk persaingan sehat dan sportif hingga bentuk persaingan yang dapat meninggalkan norma-norma agama demi mendapatkan keuntungan dan pasar yang luas. Di Indonesia, dimana sebagian besar penduduknya mayoritas beragama Islam menjadi anjuran bagi pelaku bisnis muslim untuk membangun bisnis berbasis syariah. Masyarakat yang memiliki kesenangan dalam berbelanja akan sangat mempertimbangkan dan memilih untuk mengunjungi toko atau pusat perbelanjaan yang menjual berbagai macam kebutuhannya mulai dari makanan yang halal, higienis, tempat yang bersih, membeli baju yang muslim/muslimah dan berbelanja kebutuhan lainnya.

Dalam aktivitasnya, pelaku bisnis muslim harus tetap menjaga norma-norma agama dalam berbisnis. Tidak hanya berfikir untuk mencari keuntungan, namun sebagai sarana ibadah untuk mendapatkan berkah dan ridlo dari Allah swt. Salah satu usaha yang sedang berkembang saat ini adalah bisnis ritel. Bisnis ritel di Indonesia berkontribusi besar terhadap hasil Produk Domestik Bruto (PDB) dan juga menyerap tenaga kerja dalam jumlah yang besar
(Euis, 2018). Menurut Gilbert retail adalah jenis usaha yang secara langsung mengarahkan pemasarannya untuk memuaskan konsumen akhir berdasarkan organisasi penjualan barang dan jasa sebagai inti dari distribusi. Maka dari itu, bisnis ritel merupakan distribusi terakhir yang menghubungkan antara produsen dan konsumen (Ongky, 2015). Bisnis ritel memberikan kemudahan bagi konsumen dalam memperoleh kebutuhannya dengan harga yang terjangkau, pelayanan yang baik, pilihan atau ragam produk yang banyak dan sebagainya. Sehingga pelaku ritel harus mampu membangun citra yang positif di mata konsumen, pelayanan yang prima, tempat yang bersih dan nyaman, berlaku adil dan tidak menipu dan berbagai unsur lainnya. Satu hal yang menarik dari sebuah bisnis khususnya bisnis ritel, dibandingkan dengan ritel pada umumnya adalah penerapan atribut Islamic store, serta bentuk promosi atau pemasaran yang mengusung tema Islamic. Apabila kita amati, bisnis-bisnis yang ada banyak mengusung tema chinies atau glamour atau kebarat-baratan, maka lain halnya dengan bisnis yang ada di Ponorogo Jawa Timur.

Hampir di sepanjang jalan di kota Ponorogo terdapat bentuk usaha ritel mulai dari makanan, pakaian, buah-buahan, toko emas, toko elektronik, dan lain sebagainya. Salah satu usaha ritel yang berbeda dibanding dengan usaha yang lainnya yaitu La-Tansa Gontor Departemen Store yang identik dengan nuansa islamic-nya, yang terletak di jalan Soekarno-Hatta, Kecamatan Ponorogo, Kabupaten Ponorogo. LaTansa Gontor Departement Store merupakan salah satu unit usaha milik Pondok Modern Darussalam Gontor 
yang di kelola berdasarkan sistem proteksi. Artinya unit usaha ini dikelola secara mandiri oleh para guru dan sebagian santri lembaga pendidikan tersebut, untuk mengembangkan pembangunan, dan mencukupi segala kebutuhan Pondok Modern Darussalam Gontor dan bukan untuk memperoleh keuntungan pribadi para pengelola dari penghasilan unit usaha tersebut. Hal ini juga merupakan wujud Panca Jiwa pondok yang telah ditanamkan oleh trimurti pendiri pondok, yang menegaskan bahwa pondok kepada semua guru dan santrinya menanamkan jiwanya dengan keikhlasan, kesederhanaan, berdikari atau kemandirian, ukhuwwah Islamiyyah, dan kebebasan(Panca jiwa Gontor, 2018).

Dari latarbelakang diatas, peneliti tertarik untuk melakukan analisis terhadap implementasi Islamic store attributes dan bauran pemasaran Islam yang yang diterapkan oleh La-Tansa Departement Store.

\section{Tinjauan Pustaka}

Adapun landasan teori pada penelitian ini yaitu Islamic Store Attributes dan Bauran Pemasaran Islam yang akan diuraikan sebagai berikut:

\section{Atribut Toko Islam (Islamic Store Attributes)}

Atribut dapat diartikan sebagai semua faktor-faktor yang menjadi penilaian konsumen untuk pengambilan keputusan pembelian. Faktor-faktor tersebut dapat berupa barang atau jasa beserta komponen pendukungnya berupa iklan, pelayanan pemasar, tempat pendistribusian dan lain-lain hingga produk/jasa tersebut dapat digunakan oleh konsumen (Hamzah, 2016). Atribut toko merupakan seluruh faktor-faktor yang menjadi penilaian konsumen terhadap suatu toko yang menimbulkan ketertarikan melalui pengamatan, pendengaran, perasaan, pengalaman para konsumen. Dari pengertian diatas maka dapat disimpulkan bahwa atribut toko dapat berupa fasilitas-fasilitas yang terdapat pada toko, barang jualan, suasana toko, harga, promosi, alat dalam transaksi dan lain sebagainya.

Secara khusus, Islamic store mempunyai beberapa atribut yang unik yang berbeda dengan toko retail konvensional. Dari beberapa dimensi pada Islamic store attribute diantaranya seperti produk muslim, suasana Islam, humanistik, produk halal dan nilai-nilai Islam (Waida, 2016)

1. Produk Muslim

Produk muslim mengacu pada produk yang diproduksi oleh produsen muslim dan produsen muslim tersebut merupakan orang yang saleh dan bertaqwa kepada Allah SWT. Mereka akan menggunakan produk yang tidak hanya halal dalam hal logo, tetapi mereka sangat memperhatikan konsep tayyib (halal dan tayyib). Konsumen muslim akan memastikan bahwa produk yang dibeli bersih, etis, sehat, dan tidak bertentangan dengan ajaran Islam

2. Suasana Toko Islam (Islamic Store Atmosphere)

Dalam berbisnis, seorang muslim harus menciptakan suasana Islami pada toko. Suasana toko Islam (Islamic Store Atmosphere) merupakan suasana yang berasal dari budaya, adat, serta suasana lingkungan yang sesuai dengan 
syariat Islam (Waida, 2016). Sebagai contoh menggunakan musik Islami yang melodi musiknya menyebabkan konsumen ingat terhadap Allah, menyeleksi musik yang dapat membawa kepada pendekatan terhadap Allah, lantunan ayat AlQur'an, Stakeholder dengan pakaian yang pantas dan tidak berlebihan, dekorasi toko yang Islami.

3. Humanistik

Humanisme merupakan cara berpikir untuk mengemukakan konsep peri kemanusiaan sebagai fokus dan satu-satunya tujuan. Humanisme sebagai sebuah sistem pemikiran yang berdasarkan pada berbagai nilai, karakteristik, dan tindak tanduk yang dipercaya terbaik bagi manusia (Muhammad, 2014).

4. Produk Halal

Produk halal adalah produk yang dinyatakan halal menurut syariat Islam(UU pasal 1 ayat2, 2014). Produk halal merupakan produk yang bebas dari komponen yang dilarang dalam Islam dan berasal dari bahan-bahan yang tayyib, artinya bahwa produk tersebut baik untuk dikonsumsi, tidak menimbulkan kerusakan atau bahaya, tidak memabukkan, dan tidak mengandung unsur porno. Bahan-bahan pada produk halal meliputi :hewan, tumbuhan, mikroba, dan bahan yang dihasilkan melalui proses kimiawi, proses biologi, atau proses rekayasa genetik. Sedangkan bahan yang berasal dari hewan yang diharamkan meliputi: bangkai, darah, babi dan/atau, hewan yang disembelih tidak sesuai dengan syariat.

5. Nilai Islami
Dalam berbisnis, seorang muslim harus melaksanakan bisnis sesuai dengan nilai-nilai atau peraturanperaturan yang terkandung dalam syariat Islam yang berlandaskan pada Al-Quran dan Sunnah nabi Muhammad saw. Seorang muslim diharapkan menjaga norma dan etika, dan berperikemanusiaan dalam berbisnis. Maka, Yusuf Qordhawi secara tegas telah memisahkan antara nilai-nilai dan perilaku dalam perdagangan. Di antara norma-norma atau nilai-nilai syariah itu adalah sebagai berkut

\section{a. Larangan} memperdagangkan barang-barang haram

b. Bersikap benar, amanah, dan jujur

c. Menegakkan keadilan dan mengharamkan bunga

d. Menerapkan kasih sayang dan mengharamkan monopoli

e. Menegakkan toleransi dan persaudaraan

f. Berpegang pada prinsip bahwa perdagangan adalah bekal menuju akhirat (Hasbi, 2010).

Pada nilai-nilai tersebut, pelaku bisnis muslim diharapkan untuk mentaati nilai-nilai dan perilaku dalam perdagangan, agar bisnis yang dilakukan dapat berjalan sesuai dengan syariat Islam yang telah diharapkan.

\section{Bauran Pemasaran Islam (Islamic Marketing Mix)}

Adapun definisi Pemasaran Islam berdasarkan Al-Quran, Hadits, literatur Islam dan wawancara yang dilakukan dengan cendekiawan agama Islam oleh Samir Abuznaid 
adalah"the wisdom of satisfying the needs of customers through the good conduct of delivering Halal, wholesome, pure and lawful products and services with the mutual consent of both seller and buyer for the purpose of achieving material and spiritual wellbeing in the world here and hereafter and making consumers aware of it through the good conduct of marketers and ethical advertising" (Quran,4:29)( Abuznaid,2012).

Dari pengertian diatas dapat dijelaskan bahwa Pemasaran Islam merupakan kebijaksanaan dalam memuaskan pelanggan melalui pemenuhan kebutuhan yang dilakukan dengan cara berperilaku baik yang menghantarkan kepada produk yang halal, sehat, murni dan legal dengan layanan yang disetujui bersama oleh pihak penjual dan pembeli untuk mendapatkan material yang diinginkan dan kesejahteraan spiritual dimanapun tempat berada pada masa sekarang maupun masa yang akan datang dan membuat konsumen menyadari akan perilaku yang baik dan etika dalam beriklan oleh pemasar.

Pada bauran pemasaran (Marketing mix) terdapat empat unsur atau variabel yaitu : produk (product), harga (price), tempat/ saluran distribusi (place), promosi (promotion) (Rachmawati , 2011). Namun agama Islam mempunyai perspektif tersendiri terhadap bauran pemasaran yaitu harus berlandaskan pada nilai-nilai dan konsep syariah. Berikut akan diuraikan bauran pemasaran dalam perspektif Islam.

\section{Produk (Product)}

Allah SWT berfirman dalam surat Al-Baqarah ayat 168 yang artinya:
"Wahai manusia! Makanlah yang halal lagi baik yang terdapat di bumi, dan janganlah kamu mengikuti langkah-langkah setan, sesungguhnya setan itu musuh yang nyata bagimu" (Md. Mahabub Alom, 2011).

Dari ayat Al-Qur'an tersebut dapat disimpulkan bahwa penjualan produk harus halal lagi baik. Penjualan produk atau jasa harus terhindar dari yang diharamkan seperti alkohol, perjudian, pelacuran, sihir, dan lain-lain tidak diperbolehkan menurut syariah Islam meskipun mendapatkan keuntungan yang besar.

\section{Harga (Price)}

Menurut Gitosudarmo, harga adalah jumlah uang yang dibutuhkan untuk mendapatkan sejumlah barang atau jasa atau kombinasi dari keduanya(Doni Hariadi, 2012). Dalam Islam, Rachmat Syafei mengemukakan bahwa harga terjadi apabila terdapat akad pada penukaran barang yang diridhai oleh kedua belah pihak yang saling rela terhadap pertukaran barang (Muhammad ,2017). Dalam penelitian oleh $\mathrm{H}$. Muhammad Birusman Nuryadin memaparkan bahwa berbagai macam metode penetapan harga tidak dilarang oleh Islam dengan ketentuan sebagai berikut; harga yang ditetapkan oleh pihak pengusaha/pedagang tidak menzalimi pihak pembeli, yaitu tidak dengan mengambil keuntungan di atas normal atau tingkat kewajaran. Tidak ada penetapan harga yang sifatnya memaksa terhadap para pengusaha/pedagang selama mereka menetapkan harga yang wajar dengan mengambil tingkat keuntungan yang wajar (tidak di 
atas normal). Harga diridai oleh masing-masing pihak, baik pihak pembeli maupun pihak penjual, Harga ditentukan oleh kekuatan permintaan dan penawaran, para pedagang harus menerima penetapan harga oleh pemerintah untuk menimbulkan suatu keadilan bagi seluruh masyarakat.

3. Tempat/ saluran distribusi (Place)

Menurut Revanz, distribusi merupakan saluran atau alur yang dilalui oleh barang-barang dari produsen ke perantara dan akhirnya sampai ke pemakai(Doni Hariadi ,2012). Dalam Islam, bauran tempat atau saluran distribusi harus mentaati dan sesuai dengan syariat Islam diantaranya: a) distribusi saluran tidak seharusnya membuat beban hingga ke pelanggan akhir, dari segi lebih tinggi harga dan penundaan. b) tidak diperbolehkan menimbulkan penundaan sehingga pelanggan kembali ke toko berulang kali dengan demikian menyebabkan ketidaknyamanan bagi pelanggan.c) Praktik yang tidak etis dalam distribusi tanpa keamanan dan perlindungan kemasan dapat menimbulkan kemasan yang lemah pada produk. d) tujuan utama dari saluran distribusi harus menciptakan nilai dan meningkatkan standar hidup yang dengan menyediakan etis produk dan layanan yang memuaskan (Abuznaid Samir, 2012).

\section{Promosi (Promotion)}

Dalam pandangan Islam, bauran promosi harus sesuai dengan syariat Islam diantaranya: Dalam melakukan promosi tidak diperbolehkan melanggar syariah Islam, wanita tidak boleh digunakan untuk menarik atau memikat pelanggan, tidak menggunakan bahasa dan perilaku sugestif, tidak ada penggunaan unsur wanita dalam periklanan, tidak menyembunyikan fakta dan informasi, tidak manipulatif, tidak ada daya tarik seksual, tidak bersumpah atas nama Allah, tidak berlebihan atribut, tidak ada pernyataan yang salah, tidak ada iklan yang menyesatkan, tidak ada penipuan, memberi tahu kesalahan dan kekurangan produk.

\section{Metodologi Penelitian}

\section{Jenis Penelitian}

Adapun jenis penelitian dalam penilitian ini menggunakan jenis penelitian deskriptif dengan pendekatan kualitatif. Pendekatan kualitatif pada penelitian ini diharapkan mampu menghasilkan uraian yang mendalam dari data yang diperoleh melalui ucapan, tulisan, dan perilaku yang dapat diamati dalam pendeskripsian pada objek penelitian. Dalam penelitian ini peneliti mengumpulkan data-data yang berhubungan dengan implementasi Islamic store attributes dan bauran pemasaran Islam pada La-Tansa Departement Store.

Objek, Subjek, dan Lokasi Penelitian

Objek penelitian adalah variabel atau indikator pada variabel yang menjadi fokus perhatian dalam penelitian sedangkan subjek 
penelitian adalah pihak-pihak yang dijadikan sample dalam penelitian untuk memperoleh data-data penelitian. Sesuai dengan judul penelitian, objek dalam penelitian ini adalah implementasi Islamic store attribute dan bauran pemasaran Islam pada La-Tansa Departement Store, sedangkan subjek penelitian adalah direktur (owner) dan para manager La-Tansa departement Store.

Adapun lokasi pada penelitian ini berada di La-Tansa Departement Store salah satu unit usaha milik Pondok Modern Darussalam Gontor yang terletak di jalan Sultan Agung No. 21, Kec Ponorogo, Kabupaten Ponorogo.

\section{Metode Pengumpulan Data}

Dalam mengumpulkan data, peneliti menggunakan teknik yang dilakukan dengan cara observasi (pengamatan), interview (wawancara), dokumentasi dan gabungan/triangulasi (Sugiono. 2014).

\section{Hasil}

Wawancara dilaksanakan
dengan menggunakan teknik
purposive terhadap interviewer yaitu
pengelola La-Tansa Gontor
Department Store.

Paparan Implementasi Islamic Store Attributes pada La-Tansa Gontor Department Store Muslim Product

Dalam bisnis, Islamic store diharapkan untuk menyediakan barang-barang yang diproduksi oleh orang muslim. Islamic store tidak hanya menyediakan produk halal dalam hal logo, tetapi juga sangat memperhatikan konsep tayyib (halal dan tayyib). Dari hasil wawancara menyatakan:
"La-Tansa Gontor mengutamakan untuk mengambil produk dari produsen muslim walaupun masih ada produk dari non-muslim" (interviewer 1)

"Bahan-bahan pembuatan produk pada La-Tansa Gontor, khususnya pada rumah makan berasal dari suplayer muslim yang dijamin halal”. (interviewer 2)

\section{Islamic Store Atmosphere}

Dalam berbisnis, seorang muslim harus menciptakan suasana Islami pada toko agar dapat memberikan kenyamanan bagi konsumen muslim. Dari hasil wawancara Department Store menyatakan:

"Suasana tetep kita jaga karena kita disini dibawah struktur pondok modern ya suasana yang berpendidikan, pendidikan yang bagaimana ya tentunya Islami dari musik-musiknya kita usahakan dari musik yang Islami, pakaian yang sopan, produk yang disediakan kita usahakan islami, selain itu juga dari manusianya yang berjiwa Islami" (interviewer 1)

"Konsep suasana toko yang jelas karena kita pondok ya toko tema Islami dilihat darilagu-lagu yang di setel, kemudian ketika ada adzan karyawan istirahat sebentar untuk sholat, diantara sholat maghrib sampai sholat Isya didetel ayat Al-Qur'an. Kalo dari segi fisik berupa peralatan yang kita jual, kalo buku kita lebih banyak ke wacana Islam, novel, buku-buku turost, ada Al-Qur'an" (interviewer 2)

\section{Humanistik}

Sikap humanis pada Islamic store merupakan hal yang penting yang harus diterapkan. Bersikap ramah 
dalam berinteraksi dengan konsumen dan berusaha menyediakan produkproduk yang dibutuhkan konsumen akan memperkuat tali persaudaraan antar umat beragama.

\section{a. Model Pelayanan}

Pelayanan yang baik pada toko akan memberikan rasa nyaman pada konsumen. La-Tansa Gontor Department Store memberikaan pelayanan yang baik sebagaimana ungkapan para interviewer.

"La-Tansa Gontor mewajibkan karyawan untuk menerapkan $5 \mathrm{~S}$, yaitu salam, sapa, santun, senyum, sopan" (interviewer 1)

"Model pelayanan pada LaTansa Gontor menggunakan 5 , membantu mencari barang yang dibutuhkan konsumen" (interviewer 2)

"Kita menggunakan 5 S dan kita masukkan nilai-nilai Islami dari cara berpakaian dan lain sebagainya" (interviewer 3)

b. Mensejahterakan Masyarakat Sebagai pelaku bisnis muslim sangat dianjurkan untuk saling berbagi dan melengkapi terhadap sesama. La-Tansa Gontor berusaha untuk dapat mensejahterakan masyarakat .

"La-Tansa Gontor membaca pasar terlebih dahulu, yang kedua kita juga mengajukan survei barang-barang yang dibutuhkan masyarakat dan juga santri dikarenakan LaTansa Gontor merupakan distributor utama unit-unit usaha pondok" (interviewer 1) "La-Tansa Gontor mengadakan survei pasar untuk dapat memenuhi kebutuhan masyarakat dengan cara apapun. menanyakan berbagai pihak untuk mengetahui kebutuhan konsumen" (interviewer 2)

\section{c. Produk Halal}

Dalam berbisnis, seorang muslim harus menyediakan produk-roduk yang halal dan tayyib. La-Tansa Gontor Department Store menyediakan produk-produk halal sebagaimana hasil wawancara yaitu

"La-Tansa Gontor berusaha menjamin bahwa semua produk yang masuk ke toko itu halal. LaTansa Gontor juga berusaha untuk mendapatkan label halal dari MUI untuk unit rumah makan La-Tansa agar menu yang dijual dijamin halal dan aman untuk dikonsumsi" (interviewer 1)

"Produk yang terdapat di apotik La-Tansa terdapat logo Halal MUI danlabel dari dinas kesehatan. Sementara logo halal untuk rumah makan La-Tansa masih berproses untuk mendapatkannya dari MUI" (interviewer 2)

\section{Islamic Value}

a. Bersikap benar, amanah, dan jujur

La-Tansa Gontor Department Store mengharuskan semua manajer dan karyawan untuk bersikap benar, amanah dan jujur sebagaimana hasil wawancara menyatakan:

"Karyawan menerima pelanggan itu dengan betul-betul dengan tutur kata yang baik, La-Tansa Gontor mengutamakan pemudapemuda yang otomatis jujur dan fasohahnya yang baik dalam berbicara" (interviewer 1)

"La-Tansa Gontor selalu 
mengadakan breifing disetiap selesai shalat dhuha dan ketika pembagian gaji karyawan untuk memotifasi dan memberikan tausiyah kepada keryawan agar dapat menumbuhkan akhlak yang baik" (interviewer 2)

b. Mengharamkan Riba

Dalam syari'at Islam mendapatkan penghasilan secara riba merupakan perbuatan dosa yang harus dihindari oleh umat Islam. La-Tansa Gontor Department Store berusaha agar terhindar dari riba sebagaimana hasil wawancara menyatakan:

"La-Tansa Gontor berusaha agar terhindar dari riba dengan menyimpan keuangan di bank Muamalat dan berhati-hati dalam mementukan harga produk" (interviewer 1)

"La-Tansa Gontor berusaha menghindari riba dengan cara menyimpan keuangan di Administrasi pondok dan di bank muamalat" (interviewer 2)

c. Menerapkan kasih sayang, toleransi dan persaudaraan

Pelaku bisnis muslim dianjurkan untuk menerapkan kasih sayang, toleransi dan persaudaraan. Dari hasil wawancara menyatakan:

"Toko disekitar La-Tansa Gontor tidak jadikan sebagai pesaing, pesaing yang paling utama adalah stakeholder La-Tansa Gontor sendiri" (interviewer 1)

"La-Tansa Gontor menegakkan tali persaudaraan dengan berusaha berbuat ramah, berbuat baik, mengikuti beberapa kegiatan masyarakat seperti berkhutbah, menjadi imam, dan sebagainya, dan juga memberikan pelayanan yang terbaik pada masyarakat yang datang ke toko" (interviewer 2)

d. Prinsip utama adalah bekal menuju akhirat

Dari hasil wawancara menyatakan:

"La-Tansa Gontor berusaha membentuk jiwa staff dan karyawan untuk menjalankan usaha tidak semata-mata untuk memperoleh banyak keuntunangan, tetapi juga sebagai sarana dakwah. LaTansa Gontor mendidik para karyawan untuk shalat 5 waktu berjamaah, belajar membaca AlQur'an, dan dilakukannya breifing untuk menumbuhkan motifasi dalam bekerja" (interviewer 1)

"Dalam perekrutan karyawan, staff La-Tansa Gontor menerpa basik Ibadah karyawan, dengan shalat berjamaah dengan para staff, shalat dhuha, belajar AlQur'an selama beberapa bulan. Apabila diantara karyawan tidak tahan dengan peraturan tersebut maka karyawan tersebut tidak bisa diterima untuk bekerja di La-Tansa Gontor. La-Tansa Gontor memberikan hukuman kepada karyawan yang melanggar syariat" (interviewer 2)

\section{Paparan Implementasi Bauran Pemasaran dalam Perspektive Islam pada La-Tansa Gontor Department Store}

\section{Bauran Produk}

a. Murni dan halal

Dari hasil wawancara menyatakan:

"La-Tansa Gontor sangat
mengharuskan bahwa produk 
yang masuk pada toko La-Tansa itu halal, terutama pada makanan harus menggunakan bahan-bahan yang halal" (interviewer 1)

"La-Tansa Gontor selalu melihat maslahat untuk bisa bermanfaat bagi pengguna produk maupun barang" (interviewer 2)

b. Berkualitas

Dari hasil wawancara menyatakan:

"Kualitas produk kita sesuaikan dengan minat konsumen, contohnya kalau kita jual sepatu futsal misalnya, kita gak jual kualitas yang terlalu tinggi sebab kalo jual di Ponorogo gak ada yang beli" (interviewer 1)

"Kita menjual buku sesuai dengan yang lagi tenar, jika ada buku baru kita selalu promosikan" (interviewer 2)

c. Berdampak baik untuk lingkungan

Dari hasil wawancara menyatakan:

"La-Tansa Gontor menjual barang dengan mempertimbangkan

kemaslahatan pada masyarakat dan menjamin kehalalan produk" (interviewer 1)

"La-Tansa Gontor menjual barang yang bermanfaat bagi lingkungan, sebagai contoh LaTansa Book Store menjual bukubuku yang dapat digunakan untuk para santri dan menjual buku-buku perkuliahan untuk mahasiswa" (interviewer 2).

\section{Bauran harga}

a. Tanpa kecurangan
Dari hasil wawancara menyatakan:

"La-Tansa Gontor berhati-hati dalam penetapan harga supaya tidak gharar, riba, sesuai dengan tamplet" (interviewer 1)

"Setiap unit La-Tansa Gontor mempunyai kebijakan yang berbeda-beda dalam penetapan harga. Pada La-Tansa book store memberikan diskon abadi sebesar $10 \%$ dari harga pasaran, hal tersebut agar produk-produk di La-Tansa Gontor lebih murah dari harga pasaran dan dapat menarik pelanggan" (interviewer 2)

b. Diridhai oleh masing-masing pihak

Dari hasil wawancara menyatakan:

"La-Tansa Gontor selalu memberi tahu harga kepada konsumen dengan menempelkan label harga pada setiap produk" (interviewer 1)

"La-Tansa Gontor menempel label harga di setiap produk, hal tersebut dapat memudahkan pelanggan dalam mempertimbangkan pembelian produk" (interviewer 2)

"Setiap produk pada toko buku La-Tansa diberi diskon abadi sebesar $10 \%$ "(interviewer 3)

c. Sesuai kualitas produk

Dari hasil wawancara menyatakan:

"La-Tansa Gontor menjual barang sesuai kualitas barang, barang yang sedikit rusak tidak disamakan harganya dengan barang yang masih bagus" (interviewer 1) "Sebenarnya itu sudah harga pasaran, kecuali 
kalau barangnya kita ambil dari jauh maka kita bisa menambah sedikit labanya. Semakin banyak barang maka semakin murah, semakin sedikit barang yang ada maka akan lebih mahal" (interviewer 2).

\section{Promosi}

a. Tidak menggunakan wanita untuk ketertarikan

Dari hasil wawancara menyatakan:

"La-Tansa Gontor tidak menggunakan orang dalam melakukan iklan, La-Tansa Gontor terkadang menggunakan perempuan khusus barangbarang yang dijual untuk kaum perempuan dan itu menutup aurat" (interviewer 1)

"La-Tansa Gontor tidak menggunakan wanita dalam berpromosi, dalam pembuatan poster, gambar pada poster menyesuaikan dengan barang yang dipromosikan dan warnanya sesuai dengan cover buku" (interviewer 2)

b. Tidak berlebihan atribut

Dari hasil wawancara dengan menyatakan:

'Kalimat-kalimat yang ditunjukkan pada promosi untuk suatu barang harus sesuai dengan barang yang dipromosikan. Tidak melebihlebihkan diluar kualitas barang yang dipromosikan" (interviewer 1)

"Dalam pembuatan banner, poster maupun brosur desan tidak terlalu rame, dan yang terpenting adalah apa yang disampaikan dalam periklanan itu jelas" (interviewer 2)

"kita selalu mencantumkan nilai- nilai Gontornya, kalo rumah makan sendiri ada doa-doa kayak gini, dalam bikin banner misalnya konsepnya sederhana gak muluk-muluk

\section{c. Tidak manipulatif}

kualitas barang itu sendiri" Dari hasil wawancara menyatakan:

'La-Tansa Gontor melarang melakukan penipuan, berlebihlebihan, melebihkan dari pada (interviewer 1)

"Kita gak asal share dalam promosi, kalo mau share harus saya koreksi dulu" (interviewer 2)

"La-Tansa Gontor akan berpromosi sesuai dengan barang yang dijual" (interviewer 3)

buku sesuai dengan isi bukunya, menjual baju dalam penataannya sesuai dengan jenis-jenis baju" (interviewer 2)

\section{d. Tempat / Distribusi}

i. Saluran distribusi yang etis dan tidak menimbulkan kemasan rusak

Hasil wawancara menyatakan:

"La-Tansa Gontor
menjamin bahwa produk
tersebut aman dan tidak
rusak dengan mem-packging
barang dengan melapisi 2
kardus dengan ikatan yang
kuat, memplastiki apabila
barang yang didistribusikan
berada di luar Jawa"
(interviewer 1)

ii. Menutup toko pada waktu shalat Jum'at

Hasil wawancara menyatakan:

"Kita sebenarnya gak pernah tutup sihh, dadi full time, dari 
jam 8 pagi sampe jam 9 malam. Yaa paling tutupnya kalo ada acara di pondok kayak khutbatul arsy dll, pas syawwal idul fithri, idul adha, kalo jumat tutup dari jam 11 sampe jam 1 siang” (interviewer 1)

"Kita gak pernah tutup, tiap lima waktu sholat gak tutup ya paling tidak ada transaksi, kita tutupnya pas ada acara di pondok saja, sama habis liburan lah mulai dari 27 romadhon sampe 3 syawwal, pas hari jumat tutup mulai jam 11 sampe jam 1 siang” (interviewer 2)

\section{Pembahasan}

Pembahasan dalam penelitian ini yaitu bagaimana Islamic store attributes dan bauran pemasaran dalam perspektive Islam pada LaTansa Gontor Department Store diimplementasikan. Dalam hal ini akan membahas temuan dari penelitian lapangan yang berkaitan dengan Implementasi Islamic Store Attributes dan Bauran Pemasaran dalam perspective Islam pada LaTansa Gontor Department Store.

\section{Implementasi Islamic Store Attributes di La-Tansa Gontor Department Store}

\section{Islamic Product}

Produk muslim mengacu pada produk yang diproduksi oleh produsen muslim dan produsen muslim tersebut merupakan orang yang saleh dan bertaqwa kepada Allah SWT. Mereka akan menggunakan produk yang tidak hanya halal dalam hal logo, tetapi mereka sangat memperhatikan konsep tayyib (halal dan tayyib)
(Waida, 2016).

Secara keseluruhan, La-Tansa Gontor Department Store belum $100 \%$ didapat dari produsen atau distributor muslim. Walaupun demikian, pada rumah makan LaTansa semua produk dari muslim. Rumah makan La-Tansa Gontor memilih bahan yang baik dan memastikan bahwa pembuat produk sesuai syariat Islam untuk menjamin kehalalan produk. La-Tansa Gontor berusaha menjamin semua produk pada toko halal dengan memilih produk yang sudah mendapat label halal.

\section{Suasana Toko Islam (Islamic Store Atmosphere)}

Suasana toko Islam (Islamic Store Atmosphere) merupakan suasana yang berasal dari budaya, adat, serta suasana lingkungan yang sesuai dengan syariat Islam.

Hal-hal yang mendukung suasana toko Islam (Islamic Store Atmosphere) pada La-Tansa Gontor Department Store adalah lantunan ayat suci Al-Qur'an, musik-musik Islami, desain toko yang Islami, pakaian yang sopan, penampilan sederhana, produk islami, manusianya yang berjiwa Islami, manajemen yang Islami dan lainlain.

\section{Humanistik}

Model pelayanan pada LaTansa Gontor Department Store adalah dengan menggunakan konsep $5 \mathrm{~S}$, yaitu salam, sapa, senyum, sopan, santun. Lebih daripada itu, La-Tansa Gontor Department Store memasukkan nilai-nilai Islam dalam pelayanan, membantu mencarikan barang yang dibutuhkan pelanggan, laki-laki berpakaian rapi dan perempuan menutup aurat. 


\section{Produk Halal}

Produk halal merupakan produk yang bebas dari komponen yang dilarang dalam Islam dan berasal dari bahan-bahan yang tayyib. Di Indonesia, kepastian produk halal mengacu pada logo halal yang dikeluarkan oleh MUI (Majelis Ulama Indonesia).Yang mana produk tersebut sudah mendapatkan sertifikasi halal yang dapat diperjual belikan secara langsung(UU Pasal 1 ayat 2, 2014).

Secara keseluruhan, produk pada La-tansa Gontor Department Store halal dan baik. Produk pada rumah makan La-Tansa Gontor Department Store belum mendapatkan label halal MUI dikarenakan toko tersebut baru berdiri dua tahun. Walaupun demikian masih berusaha untuk mendapatkan label halal tersebut, rumah makan La-Tansa Gontor memilih bahan-bahan yang baik dan memilih produsen bahan yang sesuai dengan syariat Islam. Produk pada Apotik Latansa sudah terdapat label halal MUI dan label dari dinas kesehatan.

\section{Nilai-Nilai Islam}

Yusuf Qordhawi secara tegas telah memisahkan antara nilai-nilai dan perilaku dalam perdagangan. $\mathrm{Di}$ antara norma-norma atau nilai-nilai syariah itu adalah Larangan memperdagangkan barang-barang haram, bersikap benar, amanah, dan jujur, menegakkan keadilan dan mengharamkan bunga, menerapkan kasih sayang dan mengharamkan monopoli, menegakkan toleransi dan persaudaraan, berpegang pada prinsip bahwa perdagangan adalah bekal menuju akhirat (Hasbi Habibi. 2010).La-Tansa Gontor Department
Store dalam menjalani aktivitas usaha mengutamakan kejujuran, bersikap benar dan amanah yaitu dengan bertutur kata yang baik, berdisiplin, semangat dalam bekerja dan dilarang melanggar syariat seperti mencuri, berbohong.

La-Tansa Gontor Department Store menghindari riba dengan menyimpan keuangan pada Administrasi Pondok Modern Darussalam Gontor dan bank Muamalat, tidak mengambil bunga bank jika ada, dan berhati-hati dalam mementukan harga produk.

La-Tansa Gontor Department Store bertoleransi, menegakkan persaudaraan dan berkasih sayang terhadap masyarakat dengan cara berbuat ramah kepada pelanggan yang datang ke toko dan membuat banyak program kegiatan kemasyarakatan seperti membagibagikan baju-baju koko ke tukang parkir, santunan anak yatim, buka puasa bersama, ikut sholat subuh berjamah dengan masyarakat, mengikuti berbagai kegiatan masyarakat seperti khutbah dan imam.

Aktivitas bisnis pada LaTansa Gontor Department Store tidak hanya untuk kesejahteraan di dunia melainkan sebagai bekal untuk kehidupan akherat yaitu dengan menjalankan rutinitas ibadah seperti shalat 5 waktu berjamaah, belajar membaca Al-Qur'an, menerpa basik Ibadah karyawan, memberhentikan kegiatan ketika adzan, mengadakan perkumpulan kajian dan lain sebagainya. 


\section{A. Implementasi bauran pemasaran dalam perspective Islam di La-Tansa Gontor Department Store \\ 1. Produk (Product)}

\begin{abstract}
Dalam makalah Samir Ahmad Abuznaid memaparkan bahwa bauran produk Islam meliputi kesesuaian dengan hukum syariah, tidak ada kemasan yang lemah, halal (murni dan halal), tidak menggunakan nama Allah dalam merek dan pelabelan, berdampak baik untuk lingkungan, tidak ada kebodohan pikiran, tidak ada kerusakan pada produk, nilai daya tahan, tidak berbahaya, dan pelabelan yang akurat.
\end{abstract}

$\begin{array}{cr}\text { La-Tansa } & \text { Gontor } \\ \text { Department } & \text { Store }\end{array}$
mengharuskan bahwa produk yang masuk pada toko LaTansa itu halal. La-Tansa Gontor telah mendapatkan jaminan dari dinas kesehatan bahwa produk-produk di apotik La-Tansa aman dan halal, produk makanan LaTansa Gontor memilih bahan yang baik dan mengetahui pembuat bahan untuk memastikan kehalalan produk, La-Tansa Gontor melarang menjual buku yang dapat menyesatkan aqidah, La-Tansa Gontor memilih produk dengan melihat kemasan.

Kualitas produk pada

$\begin{array}{lr}\text { La-Tansa } & \text { Gontor } \\ \text { Department } & \text { Store } \\ \text { bergantung pada sesuaikan } \\ \text { dengan kualitas yang } \\ \text { diinginkan konsumen, La- } \\ \text { Tansa Gontor banyak } \\ \text { menjual produk yang sedang }\end{array}$

banyak diminati masyarakat, menjual barang yang baik untuk digunakan, menjual produk makanan yang halal, menjual produk dengan kemasan yang baik, dan memilih bahan produk yang baik.

La-Tansa Gontor Department Store menjual barang yang bermanfaat bagi masyarakat dengan mempertimbangkan

kemaslahatan produk pada masyarakat, menjamin kehalalan produk, menjual barang yang tidak memberi mudharat jika digunakan.

\section{Harga (Price)}

Bauran harga harus sesuai dengan syariat Islam diantaranya: tidak dengan mengambil keuntungan di atas normal, harga diridai oleh masing-masing pihak, harga ditentukan oleh kekuatan permintaan dan penawaran, para pedagang harus menerima penetapan harga oleh pemerintah untuk menimbulkan suatu keadilan bagi seluruh masyarakat (Muhammad, 2007).

La-Tansa Gontor Department Store berhatihati dalam penetapan harga agar terhindar dari gharar dan riba, La-Tansa Gontor memberikan diskon abadi untuk menarik pelanggan, La-Tansa Gontor tidak mengambil keuntungan lebih dari $50 \%$, dan menentukan harga yang wajar.

$$
\text { La-Tansa Gontor }
$$

Department Store La-Tansa Gontor menjual barang sesuai kualitas barang, 
barang yang sedikit rusak tidak disamakan harganya dengan barang yang masih bagus, La-Tansa Gontor menjual barang sesuai dengan harga pasar, LaTansa Gontor menjual barang sesuai dengan harga yang dipatok produsen, LaTansa Gontor menjual dengan harga sesuai dengan kelangkaan produk, LaTansa Gontor menetapkan harga sesuai dengan cita rasa pada makanan.

\section{Promosi (Promotion)}

Dalam pandangan Islam, bauran promosi harus sesuai dengan syariat Islam diantaranya: Dalam melakukan promosi tidak diperbolehkan melanggar syariah Islam, wanita tidak boleh digunakan untuk menarik atau memikat pelanggan, tidak menggunakan bahasa dan perilaku sugestif, tidak ada penggunaan unsur wanita dalam periklanan, tidak menyembunyikan fakta dan informasi, tidak manipulatif, tidak ada daya tarik seksual, tidak bersumpah atas nama Allah, tidak berlebihan atribut, tidak ada pernyataan yang salah, tidak ada iklan yang menyesatkan, tidak ada penipuan, memberi tahu kesalahan dan kekurangan produk (Abuznaid Samir , 2012)

La-Tansa Gontor
Department Store tidak
menggunakan orang dalam
melakukan iklan, La-Tansa
Gontor tidak menggunakan
wanita dalam berpromosi

kecuali mempromosikan barang-barang yang dijual untuk kaum perempuan, tidak ada daya tarik seksual pada promosi di La-Tansa Gontor Department Store. La-Tansa Gontor Department Store mempromosikan barang sesuai dengan barang yang di promosikan, desain La-Tansa Gontor sederhana dan menarik, desain promosi pada La-Tansa Gontor jelas untuk dilihat, La-Tansa Gontor mencantumkan nilainilai Gontor dalam berpromosi, promosi pada La-Tansa Gontor mencamtumkan

menggunakan kalimatkalimat Islami, bahasa dalam iklan pada La-Tansa Gontor sederhana dan menarik.

$$
\text { La-Tansa Gontor }
$$

Department Store melarang melakukan penipuan, melarang melebihmelebihkan promosi dari pada kualitas barang itu sendiri, La-tansa Gontor selalu mengecek desain atau iklan sebelum melakukan promosi agar terhindar dari kesalahan dalam berpromosi.

\section{Tempat/ saluran distribusi} (Place)

Dalam Islam, bauran tempat atau saluran distribusi harus mentaati dan sesuai dengan syariat Islam diantaranya distribusi saluran tidak membuat beban hingga pelanggan akhir, tidak menimbulkan penundaan bagi pelanggan, pendistribusian barang tidak menimbulkan kemasan 
rusak, menutup toko pada waktu shalat Jum'at.

La-Tansa Gontor

Department Store berusaha melayani konsumen dengan senyaman mungikin dan tidak menimbulkan beban bagi konsumen dengan selalu menjaga kebersihan, penampilan toko yang nyaman, pelatakkan barang jualan untuk mudah dilihat dan mudah dicari konsumen, menyediakan berbagai fasilitas untuk konsumen dan memberikan ruang bagi konsumen untuk memilih barang.

$$
\text { La-Tansa Gontor }
$$

Department Store La-Tansa Gontor menjamin saluran distribusi yang etis dan tidak menimbulkan kerusakan barang dengan menggunakan mobil box untuk jarak dekat dan menggunakan jasa JNE dan karbo untuk jarak pengiriman yang jauh, LaTansa Gontor berusaha memfungsikan mobil dengan efektif dan efisien, La-Tansa Gontor mengemas barang kiriman dengan baik, dan menata barang pada mobil box dengan baik.

$$
\text { La-Tansa Gontor }
$$

Department Store mulai membuka toko pada jam 08.00 WIB sampai dengan 21.00 WIB. La-Tansa Gontor menutup toko jika terdapat acara besar di Pondok Modern Darussalam Gontor. La-Tansa Gontor menutup toko pada waktu hari raya umat Islam, La-Tansa Gontor menutup toko pada waktu shalat Jum'at.

\section{Simpulan}

Berdasarkan hasil penelitian maka dapat disimpulkan bahwa:

1. Implementasi Islamic store attribute dan bauran pemasaran Islam pada La-Tansa Gontor Department Store berjalan berdasarkan nilai-nilai Pondok Modern Darussalam Gontor yaitu diterapkan pada seluruh operasional La-Tansa Gontor Department Store yang sangat mengedepankan kualitas pelayanan terbaik untuk para konsumennya, suasana toko yang Islami, kehalalan produk, dan manajer selalu mendidik para karyawan agar berperilaku baik dan bertaqwa kepada Allah SWT.

2. La-Tansa Gontor Department Store mengimplementasikan seluruh Islamic Store Attributes yaitu: Muslim Product, Islamic store atmosphere, Islamic Product, Humanistik, Islamic Value.

3. La-Tansa Gontor Department Store mengimplementasikan seluruh bauran pemasaran dalam perspektive Islam yang terdiri dari bauran produk, bauran harga, bauran promosi, bauran distribusi.

\section{Daftar Pustaka}

Birusman, N Muhammad, 2007. Harga dalam Perspektif Islam.. Jurnal Madzahib Vol. IV, No. 1, Juni 2007.

Euis Soliha. "Analisis Industri Ritel di Indonesia". Jurnal Bisnis dan Ekonomi. Vol. 15, No.2 September 2008. p. 128.

Hasbi, Habibi. 2010. Konsep Yusuf Al-Qodhrawi Tentang Norma dan Etika Ekonomi Islam Dalam Sirkulasi Perdagangan, Riau. Fakultas Syariah dan Ilmu 
Hukum Universitas Islam Negri Sultan Syarif Kasim.

Khair, Hazman 2016. Dampak Atribut Toko terhadap Keputusan Pembelian pada Indomart Dept Store di Medan" . Jurnal Ilmiah Manajemen dan Bisnis Volume 2, No 1

Mahabub, Alom dan Haque, Shariful. 2011. Marketing: an Islamic Perspective. World Journal of Social Sciences, 2011.Vol. 1, No. 3

Mahendra, Musa, interview by Faisal Setiawan Fajri. 2018. Islamic Store Attributes (04 23).

Mahendra, Musa, interview by Faisal Setiawan Fajri. 2018. Marketing Mix from Islamic Perspective (04 23).

Muhtadi, Kamal, interview by Faisal Setiawan Fajri. 2018. Islamic Store Attributes (04 23).

Muhtadi, Kamal, interview by Faisal Setiawan Fajri. 2018. Marketing Mix from Islamic Perspective (04 23).

Muhammad Idris. “ Konsep Pendidikan Humanis dalam Pengembangan Pendidikan Islam”. MIQOT Vol. XXXVIII No. 2 Juli-Desember 2014. p. 424

Ongky, Imron. 2015. Pengaruh Produk, Harga, Tempat, Promosi Ritel Modern Terhadap Keberlangsungan Usaha Ritel Tradisional di Gresik. JESTT Vol. 2. No 9.

Panca Jiwa. 90 Tahun Pondok Modern Darussalam Gontor, dalam situs https://www.gontor.ac.id/pancajiwa (diakses pada 14 Februari 2018 Pukul 14.16 HRS)

Putra, Andika, interview by Faisal Setiawan Fajri. 2018. Islamic Store Attributes (04 26).
Putra, Andika, interview by Faisal Setiawan Fajri. 2018. Marketing Mix from Islamic Perspective (04 26).

Rachmawati, Rina, Mei 2011. Peranan Bauran Pemasaran (Marketing Mix) terhadap Peningkatan Penjualan (Sebuah Kajian terhadap Bisnis Restoran). Jurnal Kompetensi Teknik Vol. 2, No. 2.

Samir, Abuznaid, 2012. Islamic Marketing, Addressing the Muslim Market. Journal of Hebron University, Palestine. An - Najah Univ. J. Res. Vol. 26, No. 6

Santoso, Joko, interview by Faisal Setiawan Fajri. 2018. Islamic Store Attributes (04 23).

Santoso, Joko, interview by Faisal Setiawan Fajri. 2018. Marketing Mix from Islamic Perspective (04 23).

Sugiono, 2014. Metode Penelitian Bisnis. Bandung: Alfabeta.

Soliha, Euis. 2008. Analisis Industri Ritel di Indonesia". Jurnal Bisnis dan Ekonomi. Vol. 15, No. 2

Undang-Undang Republik Indonesia. 2014. Jaminan Produk Halal Pasal 1 ayat 2.

Waida, Irani, M Fauzi, dkk, 2016. What Motivate Muslim Consumer to Patronage Islamic Based-retail Store?". Journal of International Review of Management and Marketing, Vol 6

Weldy, Ahmad, interview by Faisal Setiawan Fajri. 2018. Islamic Store Attributes (04 23).

Weldy, Ahmad, interview by Faisal Setiawan Fajri. 2018. Marketing Mix from Islamic Perspective (04 23). 